Article

\title{
Pricing of Biomethane Products Targeted at Private Households in Germany-Product Attributes and Providers' Pricing Strategies
}

\author{
Carsten Herbes ${ }^{1, *}$, Lorenz Braun ${ }^{2, \dagger}$ and Dennis Rube ${ }^{1, \dagger}$ \\ 1 Institute for International Research on Sustainable Management and Renewable Energy (ISR), \\ Nuertingen-Geislingen University, Neckarsteige 6-10, Nuertingen 72622, Germany; rubed@stud.hfwu.de \\ 2 Faculty of Agriculture, Economics and Management (FAVM), Nuertingen-Geislingen University, \\ Neckarsteige 6-10, Nuertingen 72622, Germany; lorenz.braun@hfwu.de \\ * Correspondence: carsten.herbes@hfwu.de; Tel.: +49-7022-201-358; Fax: +49-7022-929-216 \\ + These authors contributed equally to this work.
}

Academic Editor: Robert Lundmark

Received: 22 December 2015; Accepted: 18 March 2016; Published: 30 March 2016

\begin{abstract}
In the effort to combat global warming, renewable energies play a key role. However, most efforts are still focused on the electricity market, so renewables remain underrepresented in the heat market. Biomethane derived from biogas is an intriguing option for using renewable energy to generate heat in residential homes. However, biomethane comes at a significantly higher cost than natural gas, meaning providers have to ask a price premium from consumers. Determining a pricing strategy is thus of crucial importance. Besides cost, providers have to consider consumers' willingness-to-pay (WTP) for the product. We propose that they could draw on existing research on WTP for green electricity, albeit with some important modifications and scarce research on biomethane. To explore this proposition, we performed a first-of-its-kind analysis of providers' pricing strategies for biomethane, using both providers' published data and data provided in response to e-mail queries. Based on the features and prices of 165 biomethane-based gas products for private households in Germany, we find that features that could, according to existing research, elicit a higher WTP are not priced accordingly. As the consumer market for biomethane is still in its early development, our results suggest opportunities for providers to ask higher prices for certain biomethane-based gas products.
\end{abstract}

Keywords: biomethane; biogas; price; pricing; marketing; willingness-to-pay (WTP); consumer; renewable energy; Germany

\section{Introduction}

The effort to combat climate change is one of the key challenges of our time. To meet this challenge, governments around the world have set ambitious targets to increase the share of renewables in the national energy mix. The European Union aims for a share of $27 \%$ of renewables by 2030 [1], while in Germany, the federal government has mandated a target of $60 \%$ by 2050 [2]. Such targets, however, are typically set based on gross final energy consumption, leaving a striking imbalance between different energy markets. To illustrate: the share of renewables in the EU-28 electricity market topped $25.4 \%$ in 2013, while the share of renewables used for heating and cooling barely reached $16.5 \%$ and that for transport, i.e., biofuels, only 5.4\% [3]. In Germany, the disparity is even greater: the renewable share for heating and cooling stands at $10.6 \%$ while the electricity market boasts a strong $25.6 \%$ [3].

Due to the disproportionately small representation of renewables in the heat market, experts see a large potential for more widespread use of renewable resources in this sector [4]. While many 
renewable energy sources could be used, biogas represents an especially promising source because it can be upgraded to natural gas quality-also called "biomethane" - suitable for injection into the natural gas grid. In countries with a well-developed gas grid, the biomethane can then be made easily available to users such as private households or businesses. Such distribution proves more cost effective than many other scenarios for biogas applications.

The mechanism for such distribution is usually mass balancing. In mass balancing, rather than biomethane being physically transported from producer to consumer, the producer feeds into the gas grid a certain amount of biomethane, which is then booked into a registry, e.g., the German Biogas Register run by the semi-public organization Deutsche Energie-Agentur GmbH (dena)-the German Energy Agency. At the time of booking, the injecting plant must have an environmental auditor verify the quantity and quality - meaning the input material property profile and origin —of the biogas. The consumer buying the biogas, or the consumer's supplier, subsequently marks the quantities in the register as "used" and receives a certificate confirming its quantity and quality [5].

The number of biogas plants around the world has increased steeply. In Europe alone, there are now roughly 15,600 plants, approximately 9000 of which are in Germany [6]. While most of these plants use biogas to generate electricity on site in combined heat and power (CHP) units, a significant potential remains for upgrading this biogas to biomethane. In Europe, there are currently nearly 300 plants (282 as of 2013) following this upgrade business model [6], 165 of which, as of December 2014, in Germany [7].

Once in the gas grid, biomethane can be used in locations distant from the generating plant, whether in CHP units, as vehicle fuel or as a substitute for natural gas in a boiler used to heat a business or private household. The potential for biomethane to serve as a major renewable source in heat generation can be assessed by considering the following. Were all the biomethane produced in Germany as of 2014 used for home heating, it would provide sufficient energy to heat more than 400,000 households (own calculation based on [7]). It follows that, should biomethane become more widely produced, a broad-scale transition to its use in the energy market could take place. However, at current cost, upgrading is not yet an option for many small biogas plants.

A critical question behind this transition remains: how to make biomethane a financially viable option. One possibility would be for governments to extend their current strategy for the electricity market, namely to provide feed-in tariffs for biomethane to directly incentivize producers, an option that the French government has chosen [8] Governments could also choose an indirect scheme to incentivize the use of biomethane, an option used in Germany and Sweden. In Germany, biomethane has been added as an option to fulfill certain energy-related regulations for the construction of new buildings [4]; in Sweden, it is endorsed as vehicle fuel [9].

Government support schemes, however, tend to be costly and face growing opposition from the tax-paying public [10], two factors that may delay the integration of renewables into the energy market. This has recently led both researchers and politicians to call for faster energy market integration of all renewables [11,12]. Governments have started to respond to these demands. In Germany, known for its broad financial support for renewables, the government has taken clear steps in this direction through its recent reforms of the Renewable Energy Act [13]. These reforms push energy market integration away from reliance on guaranteed feed-in-tariffs or similar mechanisms and towards a real marketing approach that stimulates consumer demand for energy from renewable sources. Developing the marketing mix for such an approach represents a major challenge to all players in the renewable energy industry, not only those active today, but also those emerging in the future.

To develop a marketing mix, players must weigh policy choices that relate to product design, distribution, branding, communication and, of course, pricing. The latter plays the key role because consumers tend to perceive energy as a commodity [14], meaning they tend to base their purchasing decisions on price. While the opportunity for de-commoditization of energy products based on renewables does exist, utilities have rarely succeeded with attempts at differentiation. It thus comes as no surprise that price occupies a prominent and highly visible position in the 
communications of German providers of green electricity [15]. Providers of green gas-companies offering biomethane-based gas products to private households- thus have to weigh decisions carefully when developing their pricing strategies.

When making these decisions, providers confront a phenomenon from the green electricity market that may have strong and rather unpleasant spillover effects in the biomethane market. Consumers, especially in Germany, have a vast choice of green electricity products, but most of these are based on electricity from large hydropower plants in Scandinavia [16]. These plants produce hydropower at a very low price, so prices for green electricity derived from these plants are extremely low. On average, there is only a $2 \%$ premium on the rate consumers pay for green electricity over that paid for grey electricity from fossil fuel resources [17]. Sometimes green electricity rates are actually lower than the standard rates from the local electricity supplier. This pricing structure sends a strong signal to consumers that renewable energy does not have to cost more than conventional energy $[15,16]$. However, this structure cannot be sustained in the long term, not if the share of renewable electricity is to increase. Because hydropower capacity cannot be increased in many parts of the world, providers aiming to meet a greater demand for renewable electricity will have to turn to sources that have higher generation costs.

The widely held belief that renewable energy does not have to be more expensive than conventional is emphatically not true for biomethane. Costs for producing biomethane are typically $100 \%$ higher than those for natural gas, given that even big biomethane plants face generation costs of up to 7.0 EuroCt per $\mathrm{kWh}[18,19]$. This means that providers cannot simply turn to a low-price strategy like many of their counterparts in the green electricity market. The significant cost differences and the ensuing restrictions on pricing create a formidable barrier to the further expansion of biomethane into the energy market [20]. Hence the successful marketing of biomethane will require that consumers demonstrate the willingness to pay (WTP) a premium for its use. Eliciting this WTP is a daunting marketing task for providers.

Asking for a $100 \%$ price premium for their gas supply seems hardly realistic, but providers can mitigate the sticker shock by offering a mix of natural gas products with varying percentages of biomethane, e.g., $10 \%$ or $30 \%$. Still, providers have to decide what premium level they can ask and which product features they can use to elicit a higher WTP. To answer these questions, energy providers can draw on the abundant research into WTP for green electricity because the gas and electricity markets share important characteristics and there is only one existing study on customers' perception of biomethane [21]. Rational providers would thus be expected to incorporate these research findings into their pricing strategies. Therefore we built our hypotheses on the research from the market for green electricity and tried to answer the following two questions:

- What products do biomethane providers offer and at which prices?

- What connections between product features and prices can be observed?

Comparing the empirical answers to these two questions with the results from existing research on customer preferences and WTP in the green electricity market and the one study that exists on biomethane may help to uncover potential for improvement in current biomethane pricing strategies.

We do want to make clear, however, that we are not attempting in this research to measure or otherwise assess consumer's willingness-to-pay for biomethane products. While that would be an interesting line of inquiry, our research has a different focus. Our research focuses on the two questions above, investigating to what extent providers' pricing strategies reflect what is known about consumer's WTP from research into the green electricity market. To what extent are biomethane providers adopting rational pricing strategies based on what can be inferred by analogy from the research on green electricity? Are factors that are known to affect WTP in the green electricity market and biomethane market being fully exploited by biomethane providers? These are the lines of inquiry that form the focus of our research.

Customer preferences and WTP for green electricity have been widely studied [22], as we review in the next section. Provider strategies have also received attention [15]. In contrast, the biomethane 
market is not nearly as well researched. Research on biomethane has to date focused on technical and environmental protection issues [23-28]. Even when research has considered economic and business questions, the focus has been on the cost of biomethane production [29-31]. Questions concerning the marketing of biomethane have received scant attention from researchers [32] although biomethane providers face these questions every day. To date, only one study [21] looks into customers' perceptions of biomethane. However, it does not present WTP in Euro per kWh but only asks for product characteristics that lead to a higher WTP without quantifying the effects. To our knowledge, ours is the first study to research biomethane provider strategies.

In the next section, we present results from the existing research on WTP for green electricity that can be applied to the biomethane market. We also incorporate results from the abovementioned previous study on biomethane by [21]. Building on these results, we develop our hypotheses on likely connections between features of biomethane-based consumer products and prices. We then present our research methodology in Section 3, and our results in Section 4. We discuss these results in Section 5, where we also present ideas on how biomethane providers can improve their pricing strategies.

\section{How Research on WTP for Green Electricity Can Inform Biomethane Marketing}

Our underlying basic hypothesis was that providers of green energy base their pricing decisions both on cost and on their perception of customers' WTP. Since we know of only the abovementioned study of customers' perceptions of biomethane, we first approach the pricing question by looking at WTP for green electricity. Next analyzing the differences between the two markets, we develop hypotheses for providers' pricing strategies.

Researchers studying WTP for green electricity have examined numerous factors (see Herbes et al. 2015 [22] for a comprehensive overview), including:

- Consumer characteristics:

- Sociodemographic features (e.g., age, education, and income) [33-40],

- $\quad$ Psychographic features (e.g., attitudes and values) [36,41-46];

- Market design/payment vehicle (voluntary payments through purchasing green electricity vs. mandatory payment through taxes and levies) [33,41,47-51];

- Characteristics of the provider (e.g., large utility, local utility, cooperative) [52-54];

- Product characteristics (renewable technology, share of renewables in the product, local production, labels and other features) [34-36,38,47,52,55-61].

Our study looks at provider pricing decisions for biomethane products targeted at private households, so we do not look at characteristics of individual consumers. We also do not look at payment vehicles because we are not aiming at policy recommendations on voluntary vs. mandatory systems. Provider characteristics represent an interesting factor, but they cannot be changed easily. Therefore, we chose to focus on product attributes and provider pricing decisions.

Research on green electricity points to important connections between product features and WTP. Consumers in this market seem to have clear preferences in the selection of renewable technologies with solar being the most popular and bioenergy and big hydropower the least $[34,35,47,52,57,59]$. Renewables from local production seem to elicit a higher WTP than those from non-local sources $[52,53]$. Research on the influence of the share of renewables in the product is inconclusive: while Mozumder et al. [36] found that WTP strongly increased with higher shares of renewables, Goett et al. [54] report a decreasing incremental WTP for each additional kWh of renewables in the product. Forsa [21] reports a higher WTP for products containing more than $50 \%$ of biomethane. The effect of labels also seems to be unclear: Most authors agree on the low importance of labels for consumers [52,62]. Moreover, consumer knowledge of labels in the green electricity market is limited [63] and providers do not frequently use them [15]. Further, in the consumer market, sustainability certifications do not play a big role, although they are very important in the preceding steps in the value chain, e.g., in the 
production of biogas [64-66]. Quite contrary to these findings, Forsa [21] reports $42 \%$ of respondents stating a higher WTP for products with a label. Since these results contradict research findings from the electricity market, this point needs further examination.

Building on these results, let us consider those specific features of the biomethane market that differentiate it from green electricity. First, a higher share of biomethane in the final product leads to significant extra cost for the provider. Therefore we would expect to find that the biomethane content is clearly reflected in the product pricing. Second, in Germany, several laws influence the share of biomethane in the product: The Renewable Energies Heat Act (EEWärmeG) requires a minimum biomethane content of $30 \%$ if house owners are to fulfill the terms of the law by using biomethane in small CHP units [67]. The Heat Act of Baden-Württemberg, the state relying most on biomethane in the heat market, mandates a minimum content of $10 \%$ when using biomethane in non-CHP applications [68]. We would thus expect many products to offer exactly these biomethane percentages.

A third consideration is that some biomethane products carry an "extra climate protection" fee. This fee allows the providers to use part of the revenue from these products to finance climate or environmental protection projects that have nothing to do with biogas or biomethane such as climate protection projects in Brazil [69]. This "extra climate protection" fee also exists in the market for green electricity, but the only research possibly relevant to this subject examined the effect of charitable provider donations on the WTP of institutional customers [54].

Fourth, differentiation in the biomethane market is based not on different renewable technologies such as wind or solar, but on different input sources used to produce the biogas. These sources can be broadly classified as either waste or energy crops. Using energy crops for biogas production has been the subject of heated debate in Germany, a debate focusing primarily on biogas derived from maize. As one of the most important input materials for biogas plants in Germany [19], maize has been held responsible for a range of negative effects, from changes in the landscape to food shortages and the "battle for arable land" [70]. These negative effects have dominated media attention as well as public perception of biogas [71]. In reaction, in 2011 the federal government set a cap for total maize input to biogas plants [70]; in 2014, a second step was taken by eliminating the financial incentives for electricity from biogas derived from energy crops. Forsa [21] also finds $53 \%$ of the respondents stating a higher WTP for products based on biogas from waste. Given the public debate and the political reactions, we would expect that the input source used to produce the biogas plays a role in consumer decisions and hence also influences pricing decisions.

From these considerations, we developed the following hypotheses regarding the relations between biomethane product features and provider pricing strategies. Again, the supposition was that providers would consider consumer preferences for certain attributes known from previous research and that products with these attributes would be offered at comparatively higher prices:

H1: The share of biomethane in a product is positively related to the price.

$\mathrm{H} 2$ : The extra climate protection fee is related to the price.

H3: Waste as an input material is positively related to the price while energy crops are negatively related to the price.

H4: Eco-labels are positively related to the price.

These hypotheses are assumed to be non-directional. We first investigate whether a significant relationship or difference can be recognized, and then, based on the insights gained, create and use a model with a directional relationship. In this sense, it is assumed that the pricing strategies of the providers are based on product characteristics and the resulting consumer willingness to pay for these specific product features.

\section{Methods}

To research biomethane product pricing, we used the online portal Verivox. Verivox was the first price comparison portal for energy products in Germany, and in a recent analysis of electricity rate 
comparison portals Verivox received the number one ranking for service quality [72]. As $80 \%$ of all German consumers use a comparison portal to survey the market when shopping for energy [73], and Verivox is the portal of choice for most of these consumers, the site can be regarded as the German gas market as it appears to the perceptions of the German consumer.

In previous research on the pricing of renewables [74] and other products [75-77], researchers used data from comparison portals; however, one concern frequently raised about such data is that product rankings are subject to manipulation by the portal, similar to the way the ranking of search results is subject to manipulation by a search engine. To avoid this bias in our analysis, we used a complete inventory of all biomethane-based products listed on Verivox, searching region-by-region and recording prices along with product features. Among the features recorded were details on the input materials used in the biogas production process. When these were not clearly stated on the website of the provider, we contacted the provider by e-mail and asked explicitly for them. It turned out that input material profiles were rather scarce, so in many cases we did in fact need to contact the provider by e-mail for disclosure of the biogas substrate.

To ensure that results from each search were comparable, we set the parameters in the search form to the following settings:

- Search only for biogas-based products;

- One-off bonuses were not included in the price calculation;

- Contract period was set to up to 12 months;

- For the following criteria, we chose "doesn't matter": notice period, direct provider change, and "product fulfills Verivox guidelines";

- Price guarantees were not considered, since they were not available for each product;

- The following search options were deselected: package rate, deposit, advance payment and "only providers with high customer recommendation ratio";

- Number of products displayed per provider was set to "display all".

To gather as many products as possible, we checked 250 different cities all over Germany by entering the respective postal codes. Since the Renewable Energies Heat Act of Baden-Württemberg makes this southwestern German state a particularly active market, we used an even more tightly-woven search net there, recording results for all counties (Landkreise) and all cities not belonging to a county. In total, we found 170 biomethane-based products of which we removed five because no comparable pure natural gas product existed. Subsequent interviews with market participants revealed that these 165 products do in fact represent nearly the entire, if not the entire, market. Therefore, we do not believe that the more tightly-woven search net in Baden-Württemberg captured a disproportionately larger share of products from this region.

To determine the premiums for biomethane products, we also looked at comparable prices for pure natural gas offerings by the same providers. To obtain these rates and to ensure comparability to those for biomethane, we used exactly the same settings in Verivox as used for the biomethane search. Because gas prices in Germany vary widely between regions due to differing gas grid charges, pricing comparisons were made on a provider-by-provider basis and not on an average price basis. Thus, in our comparison, premiums reflect only different product characteristics, such as biomethane content; regional differences are excluded.

We chose to express the discovered biomethane premiums as a percentage of the cost of a comparable natural gas product from the same provider, normalized by the annual cost of natural gas. This choice factors out the regional variation in gas prices that result from the differing gas grid charges and allows comparison of the premiums to annual expenditures. These annual figures were calculated using the average gas consumption by German households living in a single-family home. As of 2010, this level stood at 20,207 kWh per year [78]. Premiums were then calculated as the difference between a biomethane product and the corresponding natural gas product, expressed as a percentage of the annual heating costs. 


\section{Results}

The following table (Table 1) lists the characteristics of the 165 biomethane products analyzed. The providers were municipal utilities, pure green energy providers as well as the big four energy providers; RWE AG, E.ON SE, EnBW AG and Vattenfall AB. The majority of the products-55\%-featured a biomethane content of $10 \%$, while the second most frequently represented product category was for a biomethane content of 30\%. Products featuring a 100\% biomethane content were relatively rare (8\%).

Table 1. Product characteristics.

\begin{tabular}{ccc}
\hline Biomethane Content & Products in this Category & Percentage of the Market \\
\hline $1 \%$ & 2 & $1 \%$ \\
$5 \%$ & 20 & $12 \%$ \\
$10 \%$ & 90 & $55 \%$ \\
$20 \%$ & 9 & $5 \%$ \\
$25 \%$ & 5 & $3 \%$ \\
$30 \%$ & 25 & $15 \%$ \\
$50 \%$ & 1 & $1 \%$ \\
$100 \%$ & 13 & $8 \%$ \\
\hline Total & & \\
\hline
\end{tabular}

Details on the substrates of biogas production underlying the products proved rather difficult to obtain: for $37 \%$ of all products, the providers did not disclose, even upon our request, whether their biogas stemmed from energy crops or waste. We were, however, able to determine that $25 \%$ of the products reviewed were purely from energy crops, $18 \%$ purely from waste and another $19 \%$ from a mix of energy crops and waste. Since the providers not reporting could have been unwilling to disclose the substrates because of potential negative publicity from the use of energy crops, the percentage of such in all products might be greater than $25 \%$. However, since we have no evidence supporting this figure, we assume that substrates in the non-reporting group are randomly distributed between energy crops and waste.

Only a small percentage, $15 \%$, of all products reviewed featured Eco-labels. Those used included: "Geprüftes Bio-Erdgas" (TÜV Nord, Hannover, Germany, "Green Methane Endkundenprodukt" (TÜV Süd, Munich, Germany und "Grünes Gas Label“ (Grüner Strom Label e.V., Bonn, Germany). Only 10\% of all products advertised that an extra ,climate feature' support was included in the price.

To test our hypotheses, we performed two analyses: First, we analyzed the price premiums that biomethane-based products collected over pure natural gas products. We did this on a per provider basis to analyze the differential price strategy adopted by each individual provider. Second, we analyzed differences in annual costs between providers. This approach allowed us both to draw inferences on the pricing policy of individual providers and also to examine the relation between product features and market prices. However, we did not consider the grid charges in the second case. Thus, if the grid charges are not randomly distributed over the different providers, the effects can be a combination of the influences of factors and grid charges.

\subsection{H1: The Share of Biomethane in a Product Is Positively Related to the Price}

We found that price premiums differ significantly for products in the same category, i.e., with identical biomethane content. For example, products containing 10\% biomethane command premiums depending on the provider ranging from $-1 \%$ to $+36 \%$. For those containing $30 \%$ biomethane, the premiums range from $+5 \%$ to $+40 \%$. For pure biomethane products, the range of premiums is even wider. The scatterplot in Figure 1 demonstrates both the large ranges within one product category as well as the relation between biomethane content and the price premiums charged by individual providers. 
The scatterplot shows a positive linear correlation between biomethane content and price premium. The correlation coefficient is 0.92 and the correlation is highly significant at the level of $p$-value $<2.2 \times 10^{-16}$. This result supports hypothesis H1, namely that a positive dependency of price on biomethane content would be present. This dependency tends to be stronger, the higher the proportion of biomethane in the gas product. However, the dependency does not take into account the actual costs incurred by the provider and whether they are higher for products with a higher proportion of biomethane. The actual profitability represented by the premium remains unknown.

Biomethane proportion and Price premiums of products

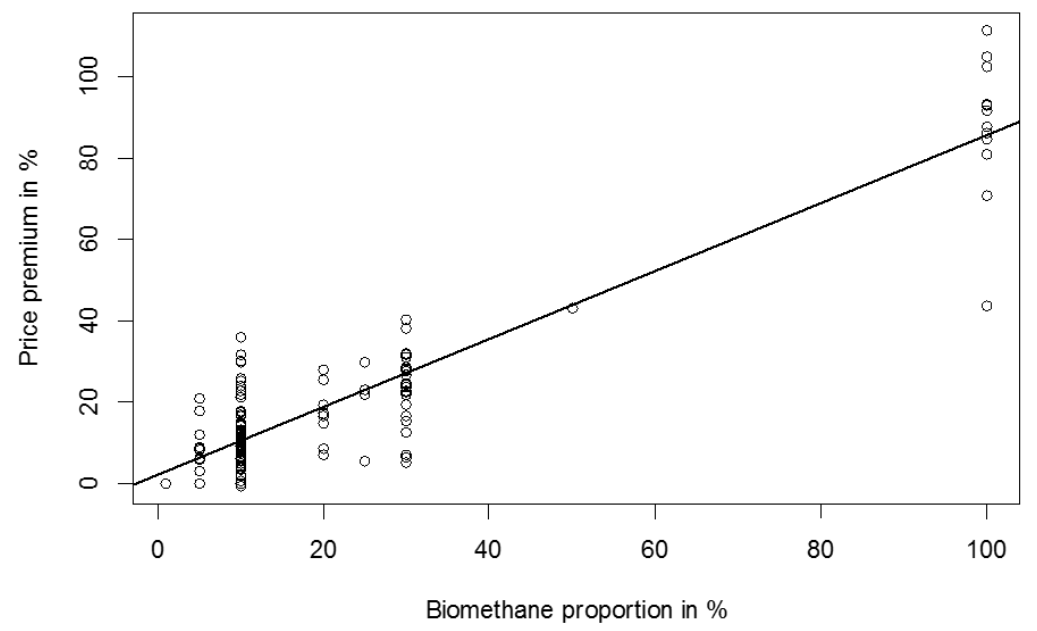

Figure 1. Relations between biomethane content and price premiums by products of individual providers.

In contrast to these findings relating price premium to biomethane content, we found no significant correlation among different providers between the annual costs and biomethane content. However, it is likely that the large differences in gas grid charges between different regions overshadow any such correlation. Some regions have grid charges that are triple those of lower cost regions. Considering that these charges account for up to $25 \%$ of the total price paid by the consumer, the masking effect of gas grid charges on price differentials is not hard to understand.

\subsection{H2: The "Extra Climate Protection" Fee Is Positively Related to the Price}

Two factors can drive this hypothesized relation: First, providers incur an additional cost in compensating for $\mathrm{CO}_{2}$ emissions by either supporting climate protection projects or buying renewable energy certificates (RECs). Second, it is reasonable to expect an additional WTP by consumers for this extra feature, inasmuch as the fee contributes to an overall greener energy ecosystem. Hence an examination is warranted of price differentials between products without and those with the "extra climate protection" fee.

Conducting such an examination by a comparison of means using a two-sample t-test, we found, indeed, a significant difference ( $p$-value $=0.00025$ ) in average annual costs. However, contrary to our expectations, the annual costs of products with the extra climate protection fee are lower $(€ 1289)$ than those for products without the fee $(€ 1488)$. Again, pricing data comparisons might be dominated by differences in gas grid charges with products carrying the extra fee being located in regions with lower grid charges. An equally important consideration, however, is, that only 16 products carried this extra climate protection fee, while 149 did not, meaning the available sample set was much smaller.

Interestingly, however, we could observe no significant differences in price premiums on a per provider basis. This means pricing strategies currently used by providers do not seem to exploit the potential for a higher WTP to support the extra climate protection feature. 


\subsection{H3: Waste as an Input Material is Positively Related to the Price While Energy Crops as Input are Negatively Related to the Price}

We tested this hypothesis again using a comparison of means. Since not all providers disclosed information on input material, the sample for analysis comprised only 104 products. The data did not show any pricing dependence on waste as an input material, neither on price premiums charged by individual providers ( $p$-value $=0.941)$ nor on market level when comparing annual costs for consumers across multiple providers ( $p$-value $=0.588$ ). Thus, the hypothesis that the use of waste is positively related to price cannot be supported.

For energy crops, the picture is not quite as clear. On a per provider basis, the average premium of $22.8 \%$ for energy crop-based products is slightly higher than the premium of $16.1 \%$ for other products $(p$-value $=0.107)$. However, on the market level, probably again due to the distorting effect of gas grid charges, energy crop-based products are slightly cheaper $(€ 1388)$ than other products $(€, 484)$ $(p$-value $=0.102)$. Therefore, we are hesitant to infer a relation between energy crops as a substrate and product price.

\subsection{H4: Eco-Labels Are Positively Related to the Price}

Of the 165 products in our analysis, only 24 had an eco-label. On a per provider basis, the comparison of means of the premiums did not reveal any significant differences ( $p$-value $=0.602$ ). This would imply that provider pricing strategies do not consider the potential positive effect of labels on consumer WTP.

On market level for the annual costs, again we see a highly significant difference, but, just as for the extra climate protection feature, one that is quite contrary to our hypothesis. Consumers pay an average annual cost of $€ 1295$ for products carrying an eco-label, which is actually less than the $€ 1417$ paid for non-labeled products ( $p$-value $=9.669 \times 10^{-7}$ ). This result is surprising given the fact that the biomethane content of the eco-label products is on average $23 \%$, higher than the average content of $21 \%$ for all products.

The ambiguous picture provided by these results led us to suspect the presence of interactions with the biomethane content: first, firstly, by the use of eco-labels and secondly by the inclusion of an extra climate protection fee. To explore for potential interactions, we divided the biomethane share into two classes: products with a proportion of biomethane less than $20 \%$ (low) and those with a proportion equal to or greater than $20 \%$ (high). We chose the $20 \%$ threshold to yield two product groups of approximately equal size. Since the price premium could be affected differently by the biomethane content depending on the extra climate protection fee and the eco-label, we used a two way analysis of variance to test for interactions. Figure 2 presents the results.

The figure on the left shows the difference in price premium between the low and high groups when a climate protection fee is present (left panel), and when the climate fee is absent (right panel). The figure on the right shows the difference when the eco-label is present (left panel) and when it is not (right panel).

The interaction between biomethane content and price premium when the climate protection fee is included in the product price shows a curious relation. If a product offers this extra climate protection feature, the proportion of biomethane has no effect on the price, but if there is no such feature, the proportion of biomethane correlates positively with a price premium $(p$-value $=0.0014)$. In other words, providers appear to price the proportion of biomethane into the product only if it has no extra climate protection feature.

The relationship between price premium, biomethane content and eco-label, as shown in the two panels on the right side of Figure 2, shows an interaction ( $p$-value $=0.0033$ ) that is perhaps more in line with expectations. For both the label present and label absent cases, the price premiums increase with increasing biomethane content. As shown in the left panel, however, this effect is stronger if the product carries an eco-label. The combination of high biomethane content and presence of an eco-label yields the highest price premium. 
Biomethane proportion / Climate Fee

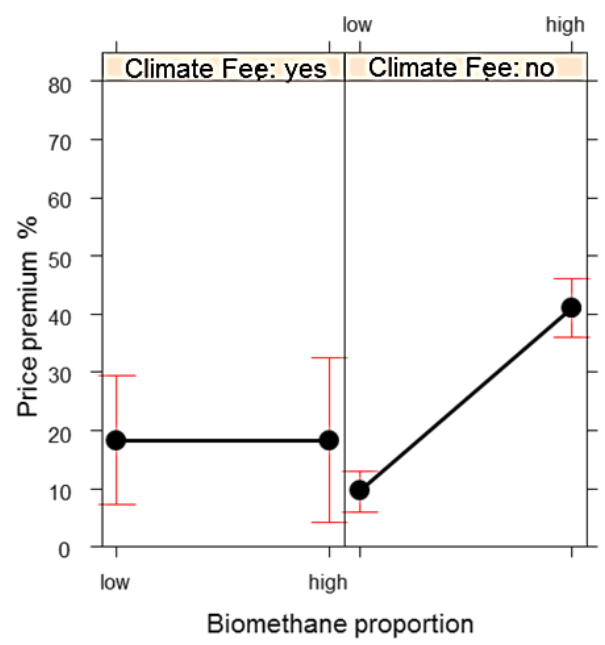

(a)

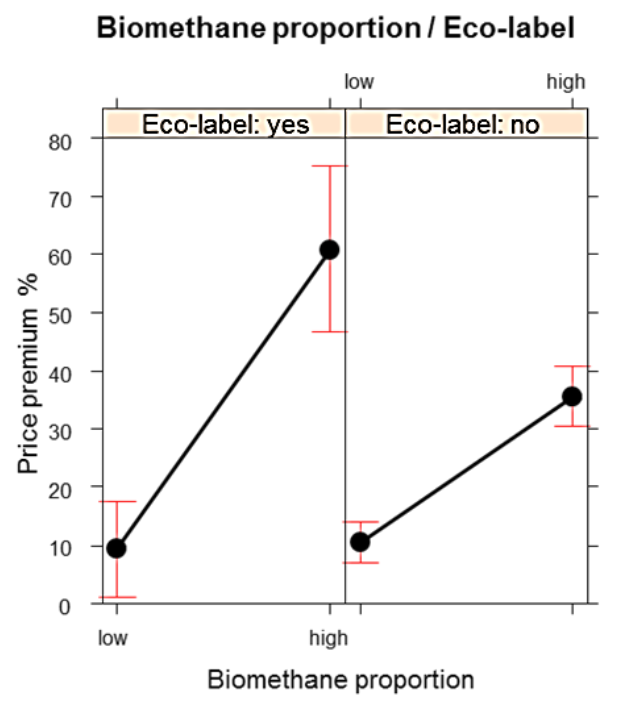

(b)

Figure 2. Interaction between biomethane content, extra climate protection fee and eco label. (a) Interaction of biomethane proportion and climate protection fee; (b) interaction of biomethane proportion and eco-label.

\section{Discussion and Conclusions}

Our study provides the first ever systematic overview of biomethane products and prices in the German market for private households. Although households choose from a large array of products, and so could be expected to respond to differentiating information, the number of products branded with eco-labels or the extra climate protection feature is relatively low.

The product portfolio reveals the strong influence of the Renewable Energies Heat Act legislation (EEWärmeG and EWärmeG Baden-Württemberg) on provider offerings. Of the 165 products analyzed, 115 contained a biomethane content of either $10 \%$ or $30 \%$, representing the respective thresholds outlined in these two regulations. We can infer from this that providers see a sizeable part of their target customer base as responding to Renewable Energies legislation and motivated toward financial gain.

Within product categories with identical biomethane contents, price premiums vary widely. This may be due to different dates of market introduction for these products. Costs for biomethane incurred by the providers have fallen in recent years, and providers can be expected to base their prices at least partly on these costs. Hence high legacy costs may explain the higher premiums of some product offerings.

The basic principle guiding our investigation was the expectation that pricing strategies would be based on relations between product characteristics and the WTP of consumers as known from existing research. However, examining in detail our four hypotheses, we find mixed results:

1. While there is a clear positive correlation between biomethane content and price on a per provider basis, the comparison of annual consumer costs across different providers does not reveal a clear picture.

2. Products with an extra climate protection feature do not collect a higher premium than products without the feature offered by the same provider. Across different providers, the former are even cheaper than the latter.

3. Neither on a per provider basis nor on an overall market basis does price show a relation to the use of energy crops or waste as the biogas substrate.

4. Eco-labels also do not directly influence price premiums on a per provider basis. On the market basis, annual consumer costs for eco-labeled products are even lower than non-labeled products. 
The results on market level for our first hypothesis as well as the counter intuitive results for hypothesis 2 and 4 on overall market level can possibly be explained by the strong influence of gas grid charges on annual costs, as these charges differ by a factor of three across regions. Further investigations on this subject are necessary.

However, these differences in gas grid charges do not apply when considering single providers, yet the only product feature that has a clear correlation to price premiums on the individual provider basis is biomethane content. Waste-based products, despite the expectation of a consumer preference for this type of biogas, are not priced any higher than gas derived from energy crops. One potential explanation for this could be that waste-based gas is cheaper for the providers, and hence they are actually collecting a higher margin, but one that is not reflected in a higher price. We also have to consider the possibility that the high number of providers that chose not to disclose their biogas substrates may have biased our results.

Overall, the observed pricing strategies partly contradict those consumer preferences that can be inferred by analogy from the research on green electricity and one study on biomethane. This opens two promising avenues for further research: first, more detailed research into consumer WTP for biomethane and second, research into the deliberations of product managers when pricing their biomethane products. Particularly informative would be a better understanding of consumer WTP. Might the negative perception of the use of energy crops as a substrate dominate consumer perceptions of biogas? Could the overarching negative perception of biogas that ensures lead consumers to regard biogas derived from energy crops and gas derived from waste as equivalent? Might biogas substrate represent a differentiating branding factor that providers have yet to exploit? The fact that there is only one study on biomethane [21] that does not quantify WTP and contradicts some results from numerous studies in the green electricity market calls for further research.

If research on consumer WTP indicates that consumer behavior in the renewable heating sector mirrors that seen in the green electricity market, there should be significant opportunities for providers to collect higher prices for products with preferential features such as the extra climate protection or the use of waste as a biogas substrate. This result would have relevance beyond the German energy market. Other countries that presently subsidize biogas may have to turn to more market-based mechanisms in the future, which means providers in those countries will need to think about pricing strategies for biomethane. Especially in France with its ambitious green energy targets and its feed-in tariff for biomethane, providers may benefit from a deeper understanding of consumer WTP for biomethane products. However the results of existing research on product attributes that drive German consumers' WTP for biomethane-based products may not be transferable to other markets. The fierce discourse on the use of energy crops may be a peculiarity of the German market.

One final aspect should also be mentioned: besides gas products based on biomethane, a plethora of products exists in the German market based on pure natural gas but offered with the extra climate protection featured in some biomethane products, i.e., with built-in financial support for pro-environmental projects. It is quite possible that consumers are unable to differentiate these products from biomethane-based products. Further research should therefore not only look at consumer preferences and WTP but also at the level of understanding that consumers have for these products and the corresponding product branding opportunities.

Acknowledgments: This work was partially supported by, and the authors thank, the Institute for International Research on Sustainable Management and Renewable Energy at Nuertingen-Geislingen University.

Author Contributions: Carsten Herbes and Dennis Rube conceived and designed the empirical research; Dennis Rube performed the data collection; Dennis Rube, Carsten Herbes and Lorenz Braun analyzed the data; and Carsten Herbes and Lorenz Braun wrote the paper.

Conflicts of Interest: The authors declare no conflict of interest. 


\section{References}

1. Bürgin, A. National binding renewable energy targets for 2020, but not for 2030 anymore: Why the European Commission developed from a supporter to a brakeman. J. Eur. Public Policy 2014, 22, 690-707. [CrossRef]

2. Energy Concept for an Environmentally Sound, Reliable and Affordable Energy Supply; Federal Ministry of Economics and Technology, Federal Ministry for the Environment, Nature-Conservation and Nuclear Safety: Berlin, Germany, 2010.

3. Eurostat. SHARES (Renewables)-Eurostat, 2015. Available online: http://ec.europa.eu/eurostat/web/ energy/data/shares (accessed on 23 July 2015).

4. Connor, P.; Bürger, V.; Beurskens, L.; Ericsson, K.; Egger, C. Devising renewable heat policy: Overview of support options. Energy Policy 2013, 59, 3-16. [CrossRef]

5. Dena. Biogasregister.de: English Information, 2015. Available online: http://www.biogasregister.de/ index.php?id=713 (accessed on 23 July 2015).

6. European Biogas Association. Number of biogas plants in Europe, 2015. Available online: http://european-biogas.eu/wp-content/uploads/2015/02/Biogas-graph-20131.png (accessed on 23 July 2015).

7. Dena. Branchenbarometer Biomethan. Daten, Fakten und Trends zur Biomethaneinspeisung, 2014. Available online: http:/ / www.biogaspartner.de/branchenbarometer.html (accessed on 23 July 2015).

8. Ministère de L'écologie, du Développement Durable et de L'énergie. Pour L'injection Dans les Réseaux de gaz Naturel: Un Tarif D’achat du Biométhane Injecté, 2015. Available online: http://www.developpement-durable.gouv.fr/Pour-l-injection-dans-les-reseaux.html (accessed on 23 July 2015).

9. Olsson, L.; Fallde, M. Waste(d) potential: A socio-technical analysis of biogas production and use in Sweden. J. Clean. Prod. 2015, 98, 107-115. [CrossRef]

10. Wunderlich, C. Akzeptanz und Bürgerbeteiligung für Erneuerbare Energien, Erkenntnisse aus Akzeptanz-und Partizipationsforschung, 2012. Available online: http://www.unendlich-viel-energie.de/ mediathek/hintergrundpapiere/akzeptanz-und-buergerbeteiligung-fuer-erneuerbare-energien (accessed on 15 September 2015).

11. Boie, I.; Fernandes, C.; Frías, P.; Klobasa, M. Efficient strategies for the integration of renewable energy into future energy infrastructures in Europe-An analysis based on transnational modeling and case studies for nine European regions. Energy Policy 2014, 67, 170-185. [CrossRef]

12. Gawel, E.; Purkus, A. Promoting the market and system integration of renewable energies through premium schemes-A case study of the German market premium. Energy Policy 2013, 61, 599-609. [CrossRef]

13. Lang, M.; Lang, A. The 2014 German Renewable Energy Sources Act revision-From feed-in tariffs to direct marketing to competitive bidding. J. Energy Nat. Resour. Law 2015, 33, 131-146. [CrossRef]

14. Kaltefleiter, B.; Enke, M. Ansätze zur De-Commoditisierung im Energiesektor-Das Fallbeispiel VNG. In Commodity Marketing_Grundlagen, Besonderheiten, Erfahrungen: 2. Auflage; Enke, M., Geigenmüller, A., Eds.; Gabler: Wiesbaden, Germany, 2011; pp. 479-490.

15. Herbes, C.; Ramme, I. Online marketing of green electricity in Germany-A content analysis of providers' websites. Energy Policy 2014, 66, 257-266. [CrossRef]

16. Herbes, C. Marketing green electricity: How green is your green electricity? Sun Wind Energy 2014, 10, 20-24.

17. Top Agrar Online. Teurer Ökostrom Ist ein Irrglaube. Retrieved, 12 April 2013. Available online: http://www.topagrar.com/news/Energie-Energienews-Oekostrom-nichtteurer (accessed on 12 April 2013).

18. Grope, J. Ökonomische Analyse der Nutzungsmöglichkeiten von Biomethan, 2013. Available online: http://www.biogasundenergie.de/downloads/scholwin_publication_16.pdf (accessed on 23 February 2016). (In German)

19. Agency for Renewable Resources. Bioenergy in Germany: Facts and Figures (January 2014); FNR: Guelzow, Germany, 2014.

20. Poeschl, M.; Ward, S.; Owende, P. Prospects for expanded utilization of biogas in Germany. Renew. Sustain. Energy Rev. 2010, 14, 1782-1797. [CrossRef]

21. Forsa. Vorstellungen und Erwartungen der Verbraucher in Bezug auf Biogasangebote; Bericht: Berlin, Germany, 2013. 
22. Herbes, C.; Friege, C.; Baldo, D.; Mueller, K.-M. Willingness to pay lip service? Applying a neuroscience-based method to WTP for green electricity. Energy Policy 2015, 87, 562-572. [CrossRef]

23. Power, N.M.; Murphy, J.D. Which is the preferable transport fuel on a greenhouse gas basis; biomethane or ethanol? Biomass Bioenergy 2009, 33, 1403-1412. [CrossRef]

24. Adams, P.; Mezzullo, W.G.; McManus, M.C. Biomass sustainability criteria: Greenhouse gas accounting issues for biogas and biomethane facilities. Energy Policy 2015, 87, 95-109. [CrossRef]

25. Acosta-Michlik, L.; Lucht, W.; Bondeau, A.; Beringer, T. Integrated assessment of sustainability trade-offs and pathways for global bioenergy production: Framing a novel hybrid approach. Renew. Sustain. Energy Rev. 2011, 15, 2791-2809. [CrossRef]

26. Britz, W.; Delzeit, R. The impact of German biogas production on European and global agricultural markets, land use and the environment. Energy Policy 2013, 62, 1268-1275. [CrossRef]

27. Huttunen, S.; Manninen, K.; Leskinen, P. Combining biogas LCA reviews with stakeholder interviews to analyse life cycle impacts at a practical level. J. Clean. Prod. 2014, 80, 5-16. [CrossRef]

28. Poeschl, M.; Ward, S.; Owende, P. Environmental impacts of biogas deployment-Part II: Life cycle assessment of multiple production and utilization pathways. J. Clean. Prod. 2012, 24, 184-201. [CrossRef]

29. Balussou, D.; Kleyböcker, A.; McKenna, R.; Möst, D.; Fichtner, W. An Economic Analysis of Three Operational Co-digestion Biogas Plants in Germany. Waste Biomass Valoriz. 2012, 3, 23-41. [CrossRef]

30. Schinnerl, D., Bleyl-Androschin, J.W., Eder, M., Eds.; Wirtschaftlichkeit von Biomethan Nutzungspfaden; Technischen Universität Graz: Graz, Austria, 2010. (In German)

31. Daniel-Gromke, J.; Denysenko, V.; Barchmann, T.; Reinel, T.; Trommler, M. Aufbereitung von Biogas zu Biomethan und Dessen Nutzung, Status Quo und Perspektiven, 2014. Available online: http:/ / www.vivis.de/index.php?option=com_phocadownload\&view=category\&id=90:biogasvergaerung\& Itemid=206ved=0CCEQFjAA\&url=http\%3A\%2F\%2Fwww.vivis.de\%2Fphocadownload\%2F2014_is\%2F2014_ IS_133_150_Daniel_Gromke_neu.pdf\&ei=kI3YVIbJMsHesATznoLACQ\&usg=AFQjCNEgnNAbQKKZLcuY 8rjpzST3Nsy28g\&bvm=bv.85464276,d.ZGU (accessed on 23 February 2016).

32. Herbes, C.; Hess, F. Herausforderungen in Marketing und Vertrieb von Biomethan-Ein Neuer Markt entsteht. In Tagungsband 5. Rostocker Bioenergieforum 2011; Nelles, M., Ed.; Rostock University: Rostock, Germany, 2011; Volume 30, pp. 95-110.

33. Akcura, E. Mandatory versus Voluntary Payment for Green Electricity; Working Paper No. 161; European Bank for Reconstruction and Development: London, UK, 2013.

34. Aravena, C.; Hutchinson, W.G.; Longo, A. Environmental pricing of externalities from different sources of electricity generation in Chile. Energy Econ. 2012, 34, 1214-1225. [CrossRef]

35. Kosenius, A.-K.; Ollikainen, M. Valuation of environmental and societal trade-offs of renewable energy sources. Energy Policy 2013, 62, 1148-1156. [CrossRef]

36. Mozumder, P.; Vásquez, W.F.; Marathe, A. Consumers' preference for renewable energy in the southwest USA. Energy Econ. 2011, 33, 1119-1126. [CrossRef]

37. Gossling, S.; Kunkel, T.; Schumacher, K.; Heck, N.; Birkemeyer, J.; Froese, J.; Naber, N.; Schliermann, E. A target group-specific approach to "green" power retailing: Students as consumers of renewable energy. Renew. Sustain. Energy Rev. 2005, 9, 69-83. [CrossRef]

38. Roe, B.; Teisl, M.F.; Levy, A.; Russell, M. US consumers' willingness to pay for green electricity. Energy Policy 2001, 29, 917-925. [CrossRef]

39. Yoo, S.-H.; Kwak, S.-Y. Willingness to pay for green electricity in Korea: A contingent valuation study. Energy Policy 2009, 37, 5408-5416. [CrossRef]

40. Zografakis, N.; Sifaki, E.; Pagalou, M.; Nikitaki, G.; Psarakis, V.; Tsagarakis, K.P. Assessment of public acceptance and willingness to pay for renewable energy sources in Crete. Renew. Sustain. Energy Rev. 2010, 14, 1088-1095. [CrossRef]

41. Oliver, H.; Volschenk, J.; Smit, E. Residential consumers in the Cape Peninsula's willingness to pay for premium priced green electricity. Energy Policy 2011, 39, 544-550. [CrossRef]

42. Clark, C.F.; Kotchen, M.J.; Moore, M.R. Internal and external influences on pro-environmental behavior: Participation in a green electricity program. J. Environ. Psychol. 2003, 23, 237-246. [CrossRef]

43. MacPherson, R.; Lange, I. Determinants of green electricity tariff uptake in the UK. Energy Policy 2013, 62, 920-933. [CrossRef] 
44. Savvanidou, E.; Zervas, E.; Tsagarakis, K.P. Public acceptance of biofuels. Energy Policy 2010, 38, 3482-3488. [CrossRef]

45. Nomura, N.; Akai, M. Willingness to pay for green electricity in Japan as estimated through contingent valuation method. Appl. Energy 2004, 78, 453-463. [CrossRef]

46. Hansla, A.; Gamble, A.; Juliusson, A.; Gärling, T. Psychological determinants of attitude towards and willingness to pay for green electricity. Energy Policy 2008, 36, 768-774. [CrossRef]

47. Borchers, A.M.; Duke, J.M.; Parsons, G.R. Does willingness to pay for green energy differ by source? Energy Policy 2007, 35, 3327-3334. [CrossRef]

48. Guo, X.; Liu, H.; Mao, X.; Jin, J.; Chen, D.; Cheng, S. Willingness to pay for renewable electricity: A contingent valuation study in Beijing, China. Energy Policy 2014, 68, 340-347. [CrossRef]

49. Menges, R.; Traub, S. Staat versus Markt: Konsumentenpräfenzen und die Förderung erneuerbarer Energien. Z. Energiewirtschaft 2008, 32, 262-270. [CrossRef]

50. Menges, R.; Traub, S. An Experimental Study on the Gap between Willingness to Pay and Willingness to Donate for Green Electricity. Finanzarchiv 2009, 65, 335-357. [CrossRef]

51. Wiser, R.H. Using contingent valuation to explore willingness to pay for renewable energy: A comparison of collective and voluntary payment vehicles. Ecol. Econ. 2007, 62, 419-432.

52. Kaenzig, J.; Heinzle, S.L.; Wüstenhagen, R. Whatever the customer wants, the customer gets? Exploring the gap between consumer preferences and default electricity products in Germany. Energy Policy 2013, 53, 311-322. [CrossRef]

53. Sagebiel, J.; Müller, J.R.; Rommel, J. Are consumers willing to pay more for electricity from cooperatives? Results from an online Choice Experiment in Germany. Energy Res. Soc. Sci. 2014, 2, 90-101. [CrossRef]

54. Goett, A.A.; Hudson, K.; Train, K.E. Customers' Choice among Retail Energy Suppliers: The Willingness-to-Pay for Service Attributes. Energy J. 2000, 21, 1-28. [CrossRef]

55. Ku, S.-J.; Yoo, S.-H. Willingness to pay for renewable energy investment in Korea: A choice experiment study. Renew. Sustain. Energy Rev. 2010, 14, 2196-2201. [CrossRef]

56. Ladenburg, J.; Dubgaard, A. Willingness to pay for reduced visual disamenities from offshore wind farms in Denmark. Energy Policy 2007, 35, 4059-4071. [CrossRef]

57. Navrud, S.; Braten, K.G. Consumers' preferences for green and brown electricity: A choice modelling approach. Rev. Écon. Polit. 2007, 117, 795-811. [CrossRef]

58. Grosche, P.; Schroder, C. Eliciting Public Support for Greening the Electricity Mix Using Random Parameter Techniques. Energy Econ. 2011, 33, 363-370. [CrossRef]

59. Farhar, B.C.; Houston, A.H. Willingness to Pay for Electricity from Renewable Energy; National Renewable Energy Laboratory: Golden, CO, USA, 1996.

60. Bergmann, A.; Hanley, N.; Wright, R. Valuing the attributes of renewable energy investments. Energy Policy 2006, 34, 1004-1014. [CrossRef]

61. Longo, A.; Markandya, A.; Petrucci, M. The internalization of externalities in the production of electricity: Willingness to pay for the attributes of a policy for renewable energy. Ecol. Econ. 2008, 67, 140-152. [CrossRef]

62. Truffer, B.; Markard, J.; Wüstenhagen, R. Eco-labeling of electricity-Strategies and tradeoffs in the definition of environmental standards. Energy Policy 2001, 29, 885-897. [CrossRef]

63. Mattes, A. Grüner Strom: Verbraucher sind bereit, für Investitionen in erneuerbare Energien zu zahlen. DIW-Wochenbericht 2012, 79, 2-9. (In German)

64. Scarlat, N.; Dallemand, J.-F. Recent developments of biofuels/bioenergy sustainability certification: A global overview. Energy Policy 2011, 39, 1630-1646. [CrossRef]

65. Schubert, R.; Blasch, J. Sustainability standards for bioenergy-A means to reduce climate change risks? Energy Policy 2010, 38, 2797-2805. [CrossRef]

66. Meyer, M.A.; Priess, J.A. Indicators of bioenergy-related certification schemes-An analysis of the quality and comprehensiveness for assessing local/regional environmental impacts. Biomass Bioenergy 2014, 65, 151-169. [CrossRef]

67. Loßner, M.; Gawel, E.; Herbes, C. Einsatz von Biomethan in Neubauten nach EEWärmeG-Eine Hemmnis-und Wirtschaftlichkeitsanalyse. Z. Energiewirtschaft 2012, 36, 267-283. [CrossRef]

68. Ministerium für Umwelt, Klima und Energiewirtschaft Baden-Württemberg. Erneuerbare-Wärme-Gesetz BW (EWärmeG) für Bestandsgebäude, 2010. Available online: https:/ / um.baden-wuerttemberg.de/de/ energie/energieeffizienz/erneuerbare-waerme-gesetz-bw/ (accessed on 9 February 2015). 
69. Bodensee Energie. Unsere Klimaschutzprojekte, 2015. Available online: http://www.bodensee-energie.de/ be/tarife/privatkunden-klima-gas/klimaprojekte.php (accessed on 9 February 2015).

70. Herbes, C.; Jirka, E.; Braun, J.P.; Pukall, K. Der gesellschaftliche Diskurs um den "Maisdeckel" vor und nach der Novelle des Erneuerbare-Energien-Gesetzes (EEG). 2012 The Social Discourse on the "Maize Cap" before and after the 2012 Amendment of the German Renewable Energies Act (EEG). GAIA Ecol. Perspect. Sci. Soc. 2014, 23, 100-108. [CrossRef]

71. Herbes, C.; Pusisek, A.; McKenna, R.; Balussou, D. Überraschende Diskrepanz bei Biogas: Lokal akzeptiert, global umstritten. Energiewirtschaftliche Tagesfr. 2014, 64, 53-56.

72. Deutsches Institut für Service-Qualität. Studie Energietarifrechner (24 September 2013), 2013. Available online: http:/ /disq.de/2013/20130924-Energietarifrechner.html (accessed on 25 July 2015).

73. Arms, H.; Stender, A.; Lang, V.; Seifried, A.-C. Der Strom- und Gasvertrieb im Wandel, Unabhängige Anbieter am Scheideweg, 2012. Available online: http://www.atkearney.de/documents/856314/1214638/ BIP_Der_Strom_und_Gasvertrieb_im_Wandel.pdf/ee091e7c-9406-4b23-b5b3-608f936cbecc (accessed on 24 July 2015).

74. Diaz-Rainey, I.; Ashton, J.K. Stuck between a ROC and a hard place? Barriers to the take up of green energy in the UK. Energy Policy 2008, 36, 3053-3061. [CrossRef]

75. Mizuno, T.; Nirei, M.; Watanabe, T. Closely Competing Firms and Price Adjustment: Some Findings from an Online Marketplace. Scand. J. Econ. 2010, 112, 673-696. [CrossRef]

76. McDonald, S.; Wren, C. Informative Brand Advertising and Pricing Strategies in Internet Markets with Heterogeneous Consumer Search. Int. J. Econ. Bus. 2012, 19, 103-117. [CrossRef]

77. Wenhong, L.; Chung, Q.B. Retailer reputation and online pricing strategy. J. Comput. Inf. Syst. 2010, 50, 50-56.

78. Frondel, M.; Andor, M.; Ritter, N.; Tauchmann, H.; Vance, C.; Matuschek, P.; Müller, U. Erhebung des Energieverbrauchs der Privaten Hausehalte für die Jahre 2009-2010, 2011. Available online: http://www.rwi-essen.de/media/content/pages/publikationen/rwi-projektberichte/PB_Energieverbrauchpriv-HH-2009-2010.pdf (accessed on 9 February 2015).

(C) 2016 by the authors; licensee MDPI, Basel, Switzerland. This article is an open access article distributed under the terms and conditions of the Creative Commons by Attribution (CC-BY) license (http://creativecommons.org/licenses/by/4.0/). 